\title{
Covid-19 ve Sosyal Reklamcılık: İzleyici Yorumları Üzerine Bir Araştırma
}

\section{Fatma Yasa}

\section{ÖZ}

2019 yılının sonunda Çin'in Vuhan kentinde ortaya çıkan ve tüm dünyaya yayılan Koronavirüs, hayatın her alanını olumsuz etkileyen büyük bir sağık sorunu haline gelmiştir. Şu an için emin olduğumuz tek şey ise bu salgınla beraber tüm dünyanın bir değişim sürecine girdiğidir. Küresel çapta etkisi olan diğer tüm olaylar gibi, Covid-19 salgınının da bireylerin dünyayı algılama, hayatlarını yönetme ve düşünme şekillerini değiştirme potansiyeline sahip olduğunu söylemek yanlış olmaz. Bu değişim sürecinden reklamcılık ve pazarlama faaliyetlerinin yanı sıra tüketici davranışlarının da etkilendiği ve etkilenmeye devam edeceği öngörülebilir. Bu bağlamda, bu çalışma kapsamında, Covid-19 salgını sürecinde, salgın temalı reklam içeriklerine yönelik izleyici görüşlerinin ortaya konması amaçlanmıştır. Bu amaç doğrultusunda YouTube'da Covid-19 salgını temalı reklamlara ait izleyici yorumları içerik analizi yöntemi ile incelenmiş; 2020 Mart ayında yayınlanan 8 reklama ait 444 adet izleyici yorumu analiz edilmiştir. Araştırma sonuçlarına göre Covid - 19 temalı reklamlarda en yüksek oranda beğenilen unsur reklamın duygusal oluşudur; reklam veren markaya yönelik değerlendirmelerde ise belirleyici olan ana unsurun milli değerler olduğu anlaşılmıştır. İzleyicilerin reklam veren markalardan, sürece karşı duyarlı davranmalarını gerek toplumsal yaşamı gerekse bireylerin hayatlarını kolaylaştııı ı faaliyetlerde bulunmalarını bekledikleri tespit edilmiştir.

Anahtar Sözcükler: Covid-19, Korona, YouTube Reklamları, Sosyal Reklamlar, İzleyici Yorumu, İçerik Analizi

\author{
FATMA YASA \\ Dr.Öğr.Üyesi \\ Pamukkale Üniversitesi \\ fucar@pau.edu.tr \\ ORCID ID: 0000-0002-4288-6124
}

SELÇUK ILETIŞIM DERGISI 2021; 14(3): 1259-1286

doi: 10.18094/ JOSC.877854

Geliş Tarihi: 09.02.2021 Kabul Tarihi: 17.03.2021 Yayın Tarihi: 25.07.2021 


\title{
Covid-19 and Social Advertising: A Study of Audience Comments
}

\section{Fatma Yasa}

\begin{abstract}
Identified for the first time in a Chinese city called Wuhan at the end of 2019, Corona virus spread all over the world very rapidly in a short time and has become a serious health problem that affects all aspects of life. One thing that everybody has agreed regarding this pandemic is that the world has changed a lot since then. Accordingly, it wouldn't be wrong to claim that Covid-19 pandemic has the potential to affect how individuals perceive the world, manage their lives and thinking processes just like all other globally influential developments. Thus, it might be foreseen that this change has also affected and will continue to affect advertising and marketing activities as well as consumer behaviors. Therefore, this study aims to determine audiences' opinions regarding pandemic-related advertisement contents broadcasted during Covid-19 pandemic. To achieve this purpose, 444 audience comments about eight Covid-19 related advertisements broadcasted on YouTube in March 2020 were examined by using content analysis method. According to the results of the study, what audiences like most about these advertisements is that they are emotional. Also, it was found that the main issue voiced in the comments about advertiser brands is national values. It has also been reported that audiences expect advertiser brands to be sensitive about this pandemic and initiate some activities that will make social life and lives of individuals easier.
\end{abstract}

Keywords: Covid-19, Corona, YouTube Ads, Social Ads, Audience Comments, Content Analysis

\author{
FATMA YASA \\ Asst. Prof. \\ Pamukkale University \\ fucar@pau.edu.tr \\ ORCID ID: 0000-0002-4288-6124
}

JOURNAL OF SELÇUK COMMUNICATION 2021; 14(3): 1259-1286

doi: $10.18094 /$ JOSC.877854 


\section{GiRiş}

Koronavirüs ilk kez 31 Aralık 2019'da Çin'in Hubey eyaletine bağlı Vuhan kentinde ortaya çıkmıştır. 11 Ocak 2020'de ilk can kaybının yaşanmasının ardından Vuhan yerel hükümeti, virüsün salgına dönüştüğünü açıklamış (TrEuronews, 2020); Dünya Sağlık Örgütü (WHO) 11 Şubat 2020'de koronavirüs kaynaklı hastalığa Covid-19 adını vermiştir. Sonrasında bu hastalık küresel salgın anlamına gelen "pandemi" olarak ilan edilmiştir (BBC, 2020). Şu ana dek 93,2 milyon insan dünya genelinde enfekte olmuş ve 2 milyon kişi ise Covid-19 nedeni ile yaşamını kaybetmiştir. Illk vakanın 11 Mart 2020 tarihinde görüldüğü Türkiye'de ise 14 Ocak 2021 itibari ile toplam hasta sayısı 2,36 milyon iken 23.495 kişi yaşamını yitirmişsir (Google News, 2021).

Covid-19'un hızla tüm dünyaya yayılması ile hayat çok daha karmaşık hale gelmiş ve gelecekle ilgili belirsizlikler artmıştır. Bu süreçte işletmeler ağır ekonomik kayıplarla uğrarken, insanlar ise geçim sıkıntısı ve gelecek kaygısıyla baş etmek zorunda kalmaktadırlar (Getreferralmd, 2020). Bu bağlamda salgın sürecinde hem tüketicilerin hem de işletmelerin değişim sürecinden geçtiği söylenebilir.

Covid-19'un küresel ekonomi üzerinde yarattığı durgunluk etkisinin, 1930'ların Büyük Buhranından bu yana görülmemiş bir durum olduğu ekonomistlerce vurgulanmaktadır. Bu sebeple Covid-19 salgınının, modern pazarlama tarihindeki en önemli çevresel değişikliklerden birini temsil ettiğini ve potansiyel olarak kurumsal sosyal sorumluluk (KSS), tüketici etiği ve temel pazarlama felsefesi üzerinde derin bir etkiye sahip olacağı açıktır (He \& Harris, 2020).

Tarih boyunca, orta çağdaki kara vebadan 20. yüzyılın başlarındaki İspanyol Gribine kadar, tüm salgınlar sosyal değişime yol açmıştır (Reeves, Carlsson-Szlezak, Whitaker, \& Abraham, 2020). Yüzyılı aşkın süredir dünyanın bu ölçekte bir pandemi görmediği göz önüne alındığında, bu alanda tüketici araştırmalarının sınırlı olduğu göze çarpmaktadır (Jones, Waters, Holland, Bevins, \& Iverson, 2010). Covid-19 salgınının da benzer şekilde toplumsal değişime sebep olacağı düşünüldüğünde bu süreçte tüketicide yaşanan değişimlerin araştırılması gereği ortaya çıkmaktadır. Bu doğrultuda, sosyal reklam olarak ele alınan Covid-19 salgını temalı reklamlara yönelik izleyicilerin görüşlerinin ortaya konması amacıyla bu araştırma gerçekleştirilmiştir. 


\section{KAVRAMSAL ÇERÇEVE}

\section{Sosyal Pazarlama Kavramı ve Sosyal Reklamcılık}

Temelleri 1960'lı yılların sonlarına dayanan (Kotler \& Levy, 1969) sosyal pazarlama "sosyal fikirlerin kabul edilebilirliğine etki eden programların ürün planlama, fiyatlama, iletişim, dağıtım ve pazarlama araştırması düşüncelerini de içerecek bir şekilde tasarlanması, uygulanması ve kontrolü" (Kotler \& Zaltman, 1971, s. 5) şeklinde tanımlanmaktadır. Dann (2010, s. 151) ise sosyal pazarlamayı "kalııı veya geçici bir düzlemdeki sosyal bir amacın gerçekleştirilebilmesi için hedef kitlenin davranışlarını değiştirmesine neden olan ticari pazarlama faaliyetlerinin, kurumların ve süreçlerinin uyarlanması ve benimsenmesi" şeklinde tanımlamıştır.

Sosyal pazarlamanın ana amacı kar elde etmek değil toplumsal amaçlar doğrultusunda hareket ederek uzun vadeli toplumsal çıkarları göz önünde bulundurmaktır (Mucuk, 2001, s. 16). "Kurumsal sosyal pazarlama, bir kurumun, halk sağlığını, güvenliğini, çevre ya da toplumun refahını iyileştirmeyi amaçlayan bir davranış değiştirme kampanyasının gelişimini ve/veya uygulamaya konmasını desteklediği bir araçtır" (Kotler \& Lee, 2007, s. 113). Bu bağlamda sağlık tutundurması faaliyetleri, çevre ile ilgili uygulamalar ile toplumu harekete geçirecek ve topluma katkı sağlayacak faaliyetler, eğitim gibi konular sosyal pazarlamanın uygulama alanını oluşturur (Cheng, Kotler, \& Lee, 2011; Kotler \& Lee, 2007; Kotler, Roberto, \& Lee, 2002; Öztürk, 2009). Bu bağlamda AIDS ve diyabet gibi sorunların, sağlık konulu sosyal pazarlamanın faaliyet alanı içinde yer aldığı (Kotler \& Lee, 2006) göz önünde bulundurulduğunda Covid-19 salgınına ait yürütülen iletişim faaliyetlerinin de sosyal pazarlama kapsamında ele alınması gerektiğini söylemek yanlış olmayacaktır.

Sosyal pazarlamanın önemli bir öğesi olan sosyal reklamlar ise belirli bir sosyal sorunla ilgili tarafsız bilgiyi kamu yararına sunarak hedef kitlede düşünce, tutum ve davranış değişiminin sağlanmasına yönelik bir ikna çabasıdır (Kataria \& Larsen, 2009, s. 429). Bu bağlamda sosyal reklamların en önemli özelliği kamu yararı gütmesidir (Bilgiç, 2016). Sosyal reklamlar, toplumsal sorunlara yönelik bir görüş ya da amaca yönelik olarak kamuoyunun görüşlerini etkilemek ve kamusal yarar sağlayacak davranışların ortaya çıkmasını sağlamak amacıyla yapııır. Bu açıdan öncelikli amacı kar elde etmek olan ticari reklamlardan ayrılır (Yüzer, 1989, s. 15). 
Sosyal reklamların iki tür işlevi olduğundan söz edilebilir. Bunlardan ilki, sağılık, iş güvenliği, emniyet vb. konularda veya yardıma intiyacı olan insanlarla ilgili hedef kitlede duyarlılık oluşturmaktır. Diğeri ise insanların zamanlarını ve paralarını toplumdaki önemli bir sorunun çözümü için kullanmalarını sağlayarak, bu sorundan etkilenen diğer insanlara yardım etmelerine teşvik etmektir (Bagozzi \& Moore, 1994, s. 56). Bu bağlamda Covid-19 temalı reklamların toplumda duyarlılık oluşturma amacı ile yapıldığı göz önünde bulundurulduğunda sosyal reklam statüsünde değerlendirilebileceği söylenebilir.

\section{Covid-19 Salgını ve Sosyal Reklamcılık}

Covid-19 salgını ile kurumların pazarlama faaliyetleri de bugüne dek yaşanmış diğer ekonomik ve sosyal dalgalanmalardan daha zorlayıı bir değişime maruz kalmıştır. Şirketlerin çalışma ve iş yapış şekilleri sosyal mesafe ve eve kapanma (karantina) gibi önlemlerden radikal bir şekilde etkilenmiştir (He \& Harris, 2020). Her ne kadar ekonomistler ve pazarlamacılar önceleri uzun vadeli yaklaşımları savunsalar da "gerçek dünyanın" yarattığı baskılar birçok şirketi ve yöneticiyi daha acil ve ani hareket etmeye zorlamış; bu bağlamda, nihai ve kısa vadeli hedefler, uzun vadeli ve manevi hedeflerden daha fazla desteklenir hale gelmiştir (Anwar \& El-Bassiouny, 2020).

Bu gibi kriz dönemleri işletmelerin satışları arttırmaya odaklanmak yerine hedef müşterilerini bilgilendirmek için çevrimiçi pazarlama kanallarını kullanmaya ağırlık vermeleri gereken zamanlardır (Getreferralmd, 2020). Dijital dönüşümün daha da önem kazandığı bu dönemde artık başarının ana ölçütü elde edilen kar değildir. Markalar topluma sağladıkları fayda ve sundukları değerler ölçütünde değer görecekler ve artık eskiye göre daha hızlı hareket etmek zorunda kalacaklardır (Öncü Arslanoğlu, 2020). Bu bağlamda sosyal pazarlama uygulamalarının önümüzdeki dönemde artacağı öngörülebilir.

Reklam ve medya şirketleri ise pandemiden önceki dönemlerde aylar alan kampanya ve çalışma süreçlerinden, daha hızlı hareket etmeyi gerektiren bir aşamaya geçmişlerdir. Reklamlarda kamu güvenliği kampanyalarının ağırlık kazandığı gözlemlenirken, diğer yandan rekabetin bağlamı da değişmiştir. Pandemi sırasında kurumlar, tüketiciler, halk ve hükümet herkesin iyiliği için iş birliğine intiyaç duymuşlardır. Bu bağlamda, geçmişte birbirine rakip olan kurumlar bile iş birliği yapmışlardır (He ve Harris, 2020). Türkiye'de Arçelik, ASELSAN, Baykar ve Biosys tarafından solunum cihazlarının ortaklaşa üretilmesi bu duruma örnek teşkil etmektedir (Turan, 2020). 
Bu süreçte pek çok markanın iletişim faaliyetlerinin odağında, sağlık çalışanları başta olmak üzere; evde kalamayan ve ön saflarda çalışan diğer önemli kişiler için şükran mesajlarının olduğu anlaşıımıştır (The Ad Council, 2020). Aynı zamanda Covid-19 salgını topluluk, birlik, beraberlik kavramlarına dayanan sosyal reklam ve pazarlama yaklaşımlarının ortaya çıkmasıyla sonuçlanmıştır. Bu süreçte birçok markanın pazarlama mesajlarının özünü "hepimiz bu işte birlikteyiz" kavramı oluşturmuştur. Markalar gerçekleştirdikleri iletişim faaliyetlerinde ürünlerini, hizmetlerini ve kendilerini etik ve insana yatııım yapan, toplumdan aldığını yine toplumun faydasına sunan markalar olarak konumlandıran mesajlara ağırlık vermişlerdir. Birçok reklam mesajının merkezinde herkesin Covid19'dan etkilendiği ve bu krizin birleştirici bir güç olduğu fikrinin hakim olduğu gözlenmiştir (Sobande, 2020).

Bu süreçte Türkiye'de yapılan bir araştırma (Yetkin Cılızoğlu, Dondurucu, \& Çetinkaya, 2020) pandemi sürecinde reklam içeriklerinde ortaya çıkan değişimlere ışı tutmuştur. Araştırma kapsamında Covid-19 salgını sırasında Türkiye'deki GSM operatörlerinin Youtube hesaplarında paylaştıkları reklamlarda kullanılan yaratıcı strateji/taktikler ve çekicilikler içerik analizi yöntemi esas alınarak incelenmişlerdir. Araştırma sonuçları sağık, emniyet/güven, topluluk değişkenlerinin salgın süreci ile bağlantılı olarak ortak kullanılan çekicilikler olduğunu ortaya koymuş; diğer yandan yaratıcı strateji ve taktiklerin markaya göre değişiklik gösterdiği tespit edilmiştir. Araştırma kapsamında incelenen reklamlarda ürün ve hizmetlere yönelik bilgilerin yanı sıra salgınla mücadele konusunda bilgilerin ağırlıklı olduğu; vurgulanan ana temaların sosyal mesafenin/izolasyonun sağlanması için evde kalmanın önemi, birlik/beraberlik, hijyen, diğer canlıların yaşam hakları etrafında şekillendiği ve GSM operatörlerinin sunduğu ürün/hizmetlerle kullanıcılar açısından süreci nasıl katlanılabilir hale getireceklerine dair vaatlerin sıklıkla kullanıldığı ortaya konmuştur. Ayrıca sosyal içerikleri reklamların ticari reklamlara oranla daha fazla duygusal öğe barındırdığı (Sciulli \& Bebko, 2005, s. 31-32) savı da Yetkin Cılızoğlu ve diğerlerinin (2020) araştırma sonuçları ile desteklenmiştir.

\section{Covid-19 Salgını ve Değişen Tüketici}

Son yılların en önemli küresel ekonomik ve sosyal krizine neden olan Covid-19 salgını nedeniyle insanlar günlük rutinlerini önemli ölçüde değiştirmek zorunda kalmışlar; birçok kişi uzun bir süre boyunca evinde kapalı kalmış ve sosyal ortamlardan soyutlanmıştır. Bu dönemde birçok insan yaşam tercihlerini 
yeniden gözden geçirme fırsatı bulmuş ve bunu yaparken de varoluşsal sorgulamalarla iş ve özel hayatları hakkındaki bakış açılarını yeniden değerlendirmişlerdir. İnsanlar bu tür varoluşsal problemleri sorgulamaya devam ettikçe, eylemlerinin ve deneyimlerinin anlamını sorguladıkça; kurumlar müşterileriyle olan etkileşimlerinde tüm bu olanların ne anlama gelebileceğini yeniden düşünmelidirler (Karpen \& Conduit, 2020). Çünkü Covid-19 salgını gibi büyük belirsizlik ve toplumsal değişim dönemlerinde ve sonrasında, birçok müşteri, işletmelerle öncekinden farklı şekillerde ilişki kurmaya çalışır. Covid-19 sonrasında toplumun öncelikleri ve kuruluşların benimsediği felsefelerin tüketiciler tarafından eleştirel bir şekilde yeniden değerlendirilip sorgulanması muhtemeldir (Anwar \& ElBassiouny, 2020). Dolayısıyla tüketicilerin bu süreçte markalarla nasıl bağlantı kurduklarını ortaya koymak önem arz etmektedir.

Kirk ve Rifkin (2020) çalışmalarında, Covid-19 salgınının ilk günlerindee hâkim olmaya başlayan birçok olağandışı tüketici davranışı kalıbından bazılarına ve bunların sonuçlarına dair teoriye dayalı bilgiler sunmuşlardır. Bu bağlamda pandemi döneminde tüketici davranışları üç aşamada ele alınabilir: tepki verme (ör. istifleme ve reddetme), başa çıkma (ör. sosyal bağılı̆̆ı sürdürme, kendin yap faaliyetleri, markalara ait görüş/düşüncelerini değiştirme) ve daha uzun vadeli uyumlanma (ör. tüketimde; bireysel ve sosyal kimliklerdeki potansiyel dönüştürücü değişimler). Örneğin Britanya'da yapılan bir araştırmanın sonuçlarına göre katıımcıların çoğunluğu (\%85) pandemi sürecinde ortaya çıkan kişisel veya sosyal değişimlerden bazılarının daha sonra da devam etmesini istediğini belirtmiştir (RSA, 2020). Kirk ve Rifkin'e (2020) göre tepki verme aşaması olarak değerlendirilen, tüketicilerde ilk başlarda görülen stoklama eğiliminin zamanla azaldığı anlaşılmaktadır. Tüketiciler evde bir yaşam kurmayı başarmış ve bu da beraberinde kendi kendine yeten tüketiciyi (başa çıkma aşaması) ortaya çıkarmıştır. Bu durum pandemi sonrasında pek çok kavramın (aile, ilişkiler; merhamet, tasarruf vb.) tanımının (uzun vadeli uyumlanma aşaması) büyük ölçüde değişeceğinin önemli bir göstergesidir (Öncü Arslanoğlu, 2020).

Tüketicilerin pandemi ile başa çıkma yöntemlerinden biri de markalara ait mevcut görüşlerini değiştirmektir (Kirk \& Rifkin, 2020). Dünya çapında 12.000 kişinin katıldığı Edelman Trust Barometer anketinin sonuçlarına göre (Rogers, 2020) tüketicilerin üçte ikisi markaların pandemiye tepki verme şekillerinin gelecekteki satın alma kararlarında büyük ölçüde etkili olacağını belirtmiştir. Katılımcıların üçte biri, pandemi döneminde yaşanan krize uygunsuz tepki verdiğini düşündükleri markalardan 
şimdiden vazgeçtiklerini ifade etmişlerdir. Krize uygun davranmayan markalardan vazgeçme oranının Brezilya'da \%76'ya ve Hindistan'da ise \%60'a kadar yükseldiği tespit edilmiştir. Edelman Trust araştırmasının ilgi çeken bulgularından biri de katılımcıların \%57'sinin komik veya neşeli içeriklerin bu dönemde uygunsuz olacağı görüşünde birleşmeleridir. Katıımcıların büyük çoğunluğunun markalardan beklentisi, pandeminin yarattığı olumsuz etkilerin farkında olduklarına ve ürünlerinin insanların bu süreçle başa çıkmasına nasıl yardımcı olacağına dair içerikler sunmalarıdır (Rogers, 2020).

Amerikan Reklam Ajansları Birliği (American Association of Advertising Agencies) tarafından yapılan araştırma sonuçlarına göre, katılımcıların \%43'ü salgın sırasında güvendikleri markalardan haber almayı rahatlatıcı bulduklarını söylerken, \%40'ı ise markaların salgına nası tepki verdiklerini, salgın sürecinde nasıl aksiyon aldıklarını bilmek istediklerini belirtmişlerdir. Katılımcıların sadece \%15'i herhangi bir markayı görmek veya duymak istemediğini dile getirmiştir. Bireyler pandemi sürecinde markalardan haberdar olmak ve markaların sorumluluk alarak bu zorlu süreçte nasıl hareket ettiklerini bilmek istemektedirler (Getreferralmd, 2020).

Bu gibi kriz dönemlerinde, markaların kendi çıkarlarını gözeten bir tavırla hareket ettiklerine veya fedakârlık yapmaya isteksiz olduklarına dair bir algı oluşursa markalar zor duruma düşerler (Kirk \& Rifkin, 2020). Dolayısıyla sosyal açıdan sorumlu bir konumlandırmaya sahip markaların, pandemi sırasında konumlandırma vaatlerine ihanet ettiklerine dair bir algı oluşursa tüketiciler tarafından cezalandırılmaları mümkündür (Gertner \& Rifkin, 2018; He \& Harris, 2020). Bu doğrultuda Amerikan Reklam Ajansları Birliği (Getreferralmd, 2020) ve Edelman Trust Barometer anketlerinin (Rogers, 2020) sunduğu veriler ışı̆̆ında pandemi sürecinde tüketicilerin hayatlarını kolaylaştıracak vaatler sunmayan; mizahi ve neşeli bir yaklaşım benimseyan reklamların tüketiciler tarafından hoş karşılanmayacağı söylenebilir.

Kısaca Covid-19 salgını iş yaşamından bireysel yaşamlara kadar birçok alanda köklü değişimleri beraberinde getirmiştir ve bu değişim sürecinin devam edeceği öngörülebilir bir gerçektir. Bu süreçte değişen tüketicinin, Covid-19 salgını temalı reklamlara yönelik görüşlerinin ne yönde şekillendiği ise belirsizliğini korumaktadır. Bu doğrultuda, bu çalışma kapsamında Covid-19 salgınını konu alan sosyal reklamlara yönelik tüketicilerin görüşleri aydınlatılmaya çalışılmıştır. 


\section{ARAŞTIRMANIN AMACI VE YÖNTEMI}

Bu araştırmanın amacı Covid-19 salgını temalı reklamlara yönelik izleyici görüşlerini ortaya koymaktır. Bu doğrultuda şu sorulara yanıt aranmıştır:

- İzleyici yorumlarının markalara göre dağııımı nasıldır?

- Reklama yönelik olumlu değerlendirmeler nelerdir?

- Reklama yönelik olumsuz değerlendirmeler nelerdir?

- Markaya yönelik olumlu değerlendirmeler nelerdir?

- Markaya yönelik olumsuz değerlendirmeler nelerdir?

- Markaya yönelik değerlendirmeler ile reklama yönelik değerlendirmeler arasında ilişki var mıdır?

- İzleyici yorumlarında kullanılan emojiler nelerdir?

- Araştırmanın ana amacı doğrultusunda, YouTube'da yer alan Covid-19 temalı reklamların altındaki izleyici yorumları nicel içerik analizi yöntemi ile incelenmişsir. İçerik analizinde kategorilendirme konusundaki yaklaşımlardan ilki belirli bir alanda var olan kategori sisteminin kullanılmasını esas alırken; kategorilerin önceden saptanamadığı durumlarda mesaj öğeleri araştırmacı tarafından ele alınıp kategoriler oluşturulur (Bilgin, 2010, s. 14). Bu araştırma kapsamında kullanılan kategoriler literatürde benzer bir araştırmaya rastlanmadığı için araştırmacı tarafından geliştirilmiştir.

İçerik analizinde kodlama iki düzeyde yapılabilmektedir. "Kodlar bazen bir cümleye ilişkin olabildiği gibi, bazen de bir sözcüğe ilişkin olabilmektedir" (Yıldırım \& Şimşek, 2011, s. 233). Bu araştırma kapsamında da izleyici yorumları hem cümleler hem de sözcükler esas alınarak iki düzeyde kodlanmıştır. Dolayısıyla kategoriler altında kodlanan veri sayısı toplam yorum sayısından fazla olabilmektedir.

Araştırma kapsamında ele alınan Covid-19 temalı reklamlara ait izleyici yorumları reklama ve markaya yönelik değerlendirmeler ile emojiler olmak üzere üç ana kategori altında kodlanmıştır. Reklam kategorisi altında, reklam içeriğine yönelik olumlu ve olumsuz olmak üzere iki alt kategori yer alırken; benzer şekilde markaya yönelik değerlendirmeler de olumlu ve olumsuz alt kategorileri esas alınarak analiz edilmiştir. Emoji kullanımı söz konusu olduğunda ilgili yorumun reklama ya da markaya yönelik 
olup olmadığının belirsiz olmasından dolayı emojiler ayrı bir kategori olarak kodlanmıştır. İzleyici yorumları içinde aynı emojinin birden fazla kullanılması durumunda ilgili emoji sadece bir kez kodlanırken; diğer izleyiciler ve kurum yetkililerince yorumlara verilen cevaplar ise analiz dışı bırakılmıştır. Iç̧erik analizinde esas alınan kategori ve kodlara ait tanımlamalar Ek 1.'de yer almaktadır.

Kodlama öncesinde iki kodlayıcı tarafından Turkcell reklamına ait ilk 60 yorum kodlanmış ve kategoriler belirlenmiştir. Sonrasında tüm verilerin kodlanması araştırmacı tarafından yapılmıştır. Araştırmanın güvenirliğinin ve kodlamanın yansızlığının sağlanması, içerik analizinde kullanılan kategorilerin tutarılı̆̆ının ortaya konması amacıyla kodlayıcılar arası tutarlııı yöntemine başvurulmuştur. Iç̧erik analizinin güvenilir olabilmesi için kodlayıcılar arası tutarlıık en az \%85 olmalıdır (Kassarjian, 1977, s. 14). Bu doğrultuda Arçelik reklamına ait 62 adet izleyici yorumu ikinci bir kodlayıcı tarafından yeniden kodlanmıştır. Kodlayıcılar arası uyum Cohen's Kappa analizi uygulanarak belirlenmiş ve $\% 88$ olarak tespit edilmiştir.

Benzeşik (homojen) örnekleme yönteminde araştırmacı, olabildiğince benzer özelliklere sahip birimlere ulaşarak "küçük, benzeşik bir örneklem oluşturma yoluyla belirgin bir alt grubu tanımlar" (Yıldıım \& Şimşek, 2011, s. 109). Araştırmaya dahil edilen reklamların ortak özelliği Covid-19 salgını hakkında olmalarıdır. Dolayısıyla izleyici yorumlarının incelendiği reklamlar amaçlı örnekleme yöntemlerinden benzeşik (homojen) örnekleme yöntemi ile belirlenmiştir.

Reklamların seçiminde Youtube Ads Leaderboard'un her ay en çok izlenen reklamlara yönelik verileri esas alınmıştır. Youtube Ads Leaderboard her ay Youtube'da yer alan reklamları popülerlik oranına göre sıralayarak en çok izlenen ilk on reklamı belirler. Araştırma kapsamında incelenen reklamlar sadece 2020 Mart ayı ile sınırlandırılmış olup bu tarihte YouTube Ads Leaderboard'a (Kocasu, 2020) göre en fazla izlenen on reklam filminden sekiz tanesinin Covid-19 salgınına yönelik mesaj içerdiği tespit edilmiştir. Bu sekiz adet reklam filmine ait izleyici yorumları araştırma kapsamında inceleme birimi olarak ele alınmıştır. İncelemeye tabi olan markalar ve reklamların linkleri şu şekildedir:

- Arçelik- https://www.youtube.com/watch?v=GsnGBYA7NuY\&feature=youtu.be

- Turkcell - https://www.youtube.com/watch?v=8PgwWc7nHTk

- Türkiye İş Bankası- https://www.youtube.com/watch?v=IF7PzyIVYpo\&feature=youtu.be 
- Vakıfbank- https://www.youtube.com/watch?v=v3IVHoabpQs\&feature=youtu.be

- Beko- https//www.youtube.com/watch?v=JNChaH4AGxs\&feature=youtu.be

- Yemek Sepeti- https://www.youtube.com/watch?v=gcPBnK7PRS4\&feature=youtu.be

- QNB Finans Bank -https://www.youtube.com/watch?v=ialr6CLyzRY\&feature=youtu.be

Bu araştırmanın odak noktası Covid-19 içerikli reklamlara yönelik genel izleyici görüşlerini ortaya koymaktır. Dolayısıyla izleyicilerin görüş farklılıklarının analizinde marka bir değişken olarak ele alınmamış olup markalar arasındaki farklılıklar sadece yapılan yorum sayısı üzerinden incelenmiştir. Ayrıca araştırmaya dahil edilen reklamlarda kullanılan yaratıcı yapım uygulamaları birbirinden farklı olduğu için kodlamalarda reklam müziği, dış ses, görsellik vb. öğelere yönelik yorumlar analiz dışı bırakılmıştır. Değinilen bu unsurlar araştırmanın sınırılıılarını oluşturmaktadır.

\section{BULGULAR}

Elde edilen veriler SPSS 13 programı ile analiz edilmiştir ve incelen reklamlara ait izleyici yorumlarında öne çıkan kategoriler frekans tabloları ile; kategoriler arası ilişkiler ise çapraz tablo şeklinde sunulmuştur.

Araştırma kapsamında incelenen sekiz reklam filmine ait toplam 500 adet izleyici yorumu tespit edilmiştir. Bu yorumlardan 56 tanesi izlenen reklam ile ilgili olmadığı için incelemeye dahil edilmemiş olup toplam 444 adet geçerli izleyici yorumu analiz edilmiştir.

\section{İzleyici Yorumlarının Markalara Göre Dağııımı}

İzleyici yorumlarının markalara göre dağıımına bakıldığından en yüksek yorum sayısının \%66,2 (n: 294) oran ile Turkcell'e ait olduğu anlaşılmıştır. Bunu \%14 (n:62) ile Arçelik takip etmektedir. Araştırma kapsamında incelenen diğer reklamlara ait yorum sayıları Tablo 1'deki gibidir.

Tablo1 İzleyici Yorumlarının Markalara Göre Dağılımı

\begin{tabular}{lll}
\hline MARKA & N & $\%$ \\
\hline Turkcell & 294 & 66,2 \\
Arçelik & 62 & 14 \\
Vakıf Bank & 26 & 5,9
\end{tabular}




\begin{tabular}{lll} 
İş Bankası & 22 & 5 \\
Yemek Sepeti & 20 & 4,5 \\
QNB Finans Bank & 19 & 4,3 \\
Beko & 1 & 0,2 \\
\hline TOPLAM & $\mathbf{4 4 4}$ & $\mathbf{1 0 0}$ \\
\hline
\end{tabular}

\section{Reklam İçeriğine Yönelik İzleyici Yorumları}

Bu bölümde reklam içeriğine yönelik izleyiciler tarafından yapılan yorumlara ait bulgular yer almaktadır. Reklam içeriğine yönelik değerlendirmeler olumlu ve olumsuz olmak üzere iki alt kategoride incelenmiştir.

\section{Reklam İçeriğine Yönelik Olumlu İzleyici Yorumları}

Reklamı yapııı, pozitif, yararlı, uygun şekilde niteleyen ifadeler olumlu izleyici yorumu olarak değerlendirilmiştir. Reklama yönelik izleyici yorumları incelendiğinde, toplam 189 adet olumlu değerlendirme olduğu anlaşılmıştır.

$\mathrm{Bu}$ kategori altında, reklamın duygusal olması, izleyiciyi duygulandırması olumlu değerlendirmeler arasında ilk sırada yer almıştır (\%30,2, n:57). Bu durum izleyicilerin salgın hastalık gibi ciddi bir durumun yaşandığı bu süreçte duygusal içeriklerden daha fazla hoşlandıkları şeklinde yorumlanabilir. Reklama yönelik olumlu sıfatların ise ikinci sırada en yüksek oranda dile getirildiği anlaşıımıştır (\%25,9, n:49). Reklama yönelik "efsane", "etkileyici" "harika", "bir numara", "müthiş" vb. ifadeler olumlu sıfatlar kategorisi altında değerlendirilmiştir. Diğer beğeni göstergeleri olan takdir $(\% 13,2$, $\mathrm{n}: 25)$ ve tebrik $(\% 11,6, \mathrm{n}: 22)$ ifadeleri ise olumlu sıfatları takip etmektedir. İzleyici yorumlarının kodlanması aşamasında reklam mesajının tekrar edildiği yorumlar da reklama yönelik olumlu değerlendirmeler başığı altında ele alınmıştır. Bu bağlamda "geçecek", "sabredelim" vb. türünden ifadeler reklam mesajının yinelenmesi olarak değerlendirilmiştir (\%10,1, n:19). Reklama yönelik olumlu değerlendirmeler içerisinde milli unsurlara da vurgu yapıldığı anlaşıımıştır (\%8,5, n:16). "Korona Türklerden güçlü değil”, "ne mutlu Türk'üm diyene", "Türk gibisi yok", "Türkiye güçlü bir ülke" gibi ifadeler ile birlik beraberlik çağrısı yapan izleyici yorumları milli unsurlar olarak kodlanmıştır (Tablo 2). 
Tablo 2 Reklam iç̧eriğine Yönelik Olumlu İzleyici Yorumları

\begin{tabular}{lll}
\hline YORUM içERiĞi & N & $\%$ \\
\hline Duygusallık & 57 & 30,2 \\
Olumlu sıfat & 49 & 25,9 \\
Takdir & 25 & 13,2 \\
Tebrik & 22 & 11,6 \\
Reklam mesajı yineleme & 19 & 10,1 \\
Milli Unsurlar & 16 & 8,5 \\
Sağlık çalışanları & 1 & 0,5 \\
\hline TOPLAM & $\mathbf{1 8 9}$ & $\mathbf{1 0 0}$ \\
\hline
\end{tabular}

\section{Reklam Icçeriğine Yönelik Olumsuz İzleyici Yorumları}

Reklama yönelik olumsuz izleyici yorumları reklamı yapıcı ve yararlı olmayan, hiçbir sonuca ulaşmayan, gözetilen amaca veya beklenilene uygun olmayan, menfi, negatif şekilde niteleyen ifadeleri içerir.

Reklama yönelik izleyici yorumları arasında olumsuz ifadelerin sayısı 49 olarak tespit edilmiştir. Bu kategori altında reklama yönelik olumsuz sıfatların (\%30,6, n:15) en yüksek oranda dile getirilen unsur olduğu anlaşılmıştır. Reklamın "anlamsız", "iğrenç", "gereksiz", "mantıksız" vb. olduğu yönündeki değerlendirmeler bu kategori altında ele alınmıştır. Reklamın olumsuz duygular uyandırdığı üzücü olduğu, karamsarlık verdiği, moral bozucu olduğu yönündeki eleştiriler ise ikinci sırada en yüksek oranda dile getirilmiştir $(\% 18,4, n: 9)$. Covid-19 önlemleri arasında yer alan cerrahi maske kullanımı ve sosyal mesafe kurallarının reklamlarda ihlal edildiğine yönelik eleştiriler de izleyiciler tarafından reklama yönelik yapılan olumsuz değerlendirmeler arasında yer almıştır (\%14,3, n:7). Reklamda ileri sürülen bugünlerin geçici olduğu, sabredilmesi gerektiği yönündeki mesajların reddini içeren değerlendirmeler de izleyiciler tarafından yapılmıştır $(\% 10,2, n: 5)$. Ayrıca pandemi döneminde çalışmak zorunda kalan diğer emekçilere reklamlarda yer verilmemesi de eleştirilen unsurlar arasında yer almıştır (\%8,2, n:4) (Tablo3).

Tablo 3 Reklam İçeriğine Yönelik Olumsuz İzleyici Yorumları

\begin{tabular}{lll}
\hline YORUM içERiĞi & N & $\%$ \\
\hline Olumsuz sıfat & 15 & 30,6 \\
Olumsuz duygu & 9 & 18,4 \\
Covid-19 önlemlerine uymama & 7 & 14,3 \\
Diğer & 6 & 12,2 \\
Reklam mesajını reddetme & 5 & 10,2
\end{tabular}




\begin{tabular}{lll} 
Diğer emekçilerin görülmemesi & 4 & 8,2 \\
Sık tekrar & 3 & 6,1 \\
\hline TOPLAM & $\mathbf{4 9}$ & $\mathbf{1 0 0}$ \\
\hline
\end{tabular}

\section{Markaya Yönelik İzleyici Yorumları}

Markaya yönelik izleyici yorumları, reklam içeriğinden bağımsız olarak reklam veren markaya ait ifade edilen izleyici görüşlerini kapsar. Reklam veren markaya yönelik değerlendirmeler olumlu ve olumsuz olmak üzere iki alt kategorileride incelenmiştir.

\section{Markaya Yönelik Olumlu İzleyici Yorumları}

Markayı yapıcı, pozitif, yararlı, uygun şekilde niteleyen ifadeler markaya yönelik olumlu izleyici yorumu olarak tanımlanmıştır.

Reklam veren markaya yönelik 78 adet olumlu değerlendirme içinde, markaya yönelik sevgi ifadelerinin en yüksek oranda dile getirildiği tespit edilmiştir (\%37,2, n:29). "Canım bankam", "ìyi ki Turkcelliyim”, "İş Bankam”, "lyi ki varsın” türünden ifadeler bu kategori altında sınıflandırılmıştır. Markaya teşekkürlerini sunma bu kategori altında sıklıkla rastlanan bir diğer olumlu ifadedir (\%29,5, n:23). Üçüncü sırada sıklıkla dile getirilen bir diğer kategori ise milli unsurlarla ilgili değerlendirmelerdir $(\% 16,7, n: 13)$ (Tablo 4).

Tablo 4 Markaya Yönelik Olumlu İzleyici Yorumları

\begin{tabular}{lll}
\hline YORUM içERiĞi & N & $\%$ \\
\hline Sevgi & 29 & 37,2 \\
Teşekkür & 23 & 29,5 \\
Milli Unsurlar & 13 & 16,7 \\
Duyarlılık & 12 & 15,4 \\
Ürün/hizmet Beğeni & 1 & 1,3 \\
\hline TOPLAM & $\mathbf{7 8}$ & $\mathbf{1 0 0}$
\end{tabular}

Reklamda bahsi geçen markanın ülkenin gururu olması, ülkesini sevmesi, ülkesine hizmet etmesi ve yatırımlar yapması, vatansever olması; markanın isminde Türk (Turkcell) ve Türkiye (Türkiye İş Bankası) kelimelerinin geçiyor olması milli unsurlar altında sınıflandırılan olumlu değerlendirmelerdir. Markaların salgın hastalık gibi içinde bulunulan zorlu bir süreçte gösterdiği duyarlılık ve sağladığı destekler (\%15,4, n:12) de izleyici yorumlarında yansımasını bulmuştur. Koç Grubu'nun otellerini sağlık 
çalışanlarına açması, Arçelik'in solunum cihazı üretmeye başlaması gibi sağlanan desteklerin yanı sıra markaların salgın sürecine hassasiyetle yaklaşıp güncel sorunlara duyarlı davranmaları izleyiciler tarafından olumlu değerlendirilmiştir (Tablo 4).

\section{Markaya Yönelik Olumsuz İzleyici Yorumları}

Markayı yapıcı ve yararlı olmayan, hiçbir sonuca ulaşmayan, gözetilen amaca veya beklenilene uygun olmayan, menfi, negatif şekilde niteleyen ifadeler markaya yönelik olumsuz izleyici yorumları olarak değerlendirilmiştir. Veri analizi sonucunda reklam veren markaya yönelik 73 adet olumsuz izleyici yorumu tespit edilmiştir.

Tablo 5 Markaya Yönelik Olumsuz İzleyici Yorumları

\begin{tabular}{lll}
\hline YORUM içERiĞi & N & $\%$ \\
\hline Ürün/Hizmet Şikâyet & 35 & 47,9 \\
Olumsuz Sıfat & 19 & 26 \\
Destek Olmama & 14 & 19,2 \\
Diğer & 5 & 6,8 \\
\hline TOPLAM & $\mathbf{7 3}$ & $\mathbf{1 0 0}$ \\
\hline
\end{tabular}

Bu yorumlar içinde \%47,9 (n:35) oran ile en yüksek değere sahip olan unsur ürün ve hizmetlere yönelik getirilen eleştirilerden oluşmaktadır. Faturaların yüksek gelmesi, faizlerin yüksek olması, internetin çekmemesi, müşteri hizmetlerinin yetersizliği vb. yönündeki şikayetler bu kategori altında sınıflandırılmıştır. Markaya yönelik olumlu değerlendirmeler arasında ürün/hizmetlere yönelik memnuniyet sadece $1(\% 1,3)$ kişi tarafından dile getirilmesine karşın (Tablo 4), olumsuz değerlendirmelerde ürün/hizmet şikayetlerinin sıklıkla dile getiriliyor olması dikkate değerdir. İzleyici yorumlarında sıklıkla rastlanan olumsuz sıfatlar \%26 (n:19) oran ile markaya yönelik olumsuz değerlendirmeler arasında ikinci sırada yer almaktadır. "Çıkarcı", "samimiyetsiz", "kan emici", "soyguncu", "dolandırııı", "kazıkçı", "anlayışsız", "yalancı" vb. ifadeler bu kategori altında değerlendirilmiştir. Markaların pandemi gibi zorlu bir süreçte gereken desteği sağlamamasına $(\% 19,2, n: 14)$ yönelik eleştiriler de izleyici yorumları arasında yer almaktadır. Bu bağlamda ödeme kolaylığı sağlama, bedava internet, komisyon almama vb. desteklerin ilgili markalar tarafından sunulmuyor olması eleştirilerin odağı olmuştur (Tablo 5). 


\section{Markaya ve Reklama Yönelik İzleyici Yorumları Arasındaki İlişki}

Markaya yönelik izleyici değerlendirmeleri ile reklama yönelik değerlendirmeler arasında bir ilişki olup olmadığını belirlemek için öcelikle markaya ve reklama ait izleyici yorumları altında yer alan kategoriler "olumlu" ve "olumsuz" değerledirmeler olarak iki alt kategoriye indirilerek yeniden kodlanmış; ardından verilere Ki-kare testi uygulanmıştır. Analiz sonucunda Pearson ki-kare değeri 75.259, serbestlik derecesi (Df) 1 ve P (sig.) değeri 0.00 olarak tespit edilmiştir. Bu sonuç ışığında reklamlara yönelik izleyeci yorumları ile markaya yönelik izleyici yorumları arasında bir ilişki olduğu anlaşılmıtır.

Tablo 6'da görüldüğüü üzere markaya yönelik olumsuz izleyici yorumlarının \%67,1'i (n:49) aynı zamanda reklama yönelik de olumsuz bir değerlendirme içerirken, \%32,9'u (n:24) reklama yönelik olumlu dğerlendirme içermektedir. Markaya yönelik olumlu değerlendirmeler arasında reklama yönelik olumlu yorumların oranı \%100 (n:75) olarak tespit edilmiştir. Bu bulgu ışığında markaya yönelik olumlu görüşlerin, beraberinde reklama yönelik olumlu değerlendirmeleri de getirdiği; ancak bazı durumlarda izleyicilerin markaya yönelik görüşleri olumsuz olmasına karşın reklamı olumlu değerlendirebildiği anlaşıımıştır. Bu durum reklam içeriklerinin markadan bağımsız bir şekilde değerlendirilebileceği şeklinde yorumlanabilir.

Tablo 6 Markaya ve Reklama Yönelik İzleyici Yorumları Arasındaki İlişki

\begin{tabular}{|c|c|c|c|c|c|}
\hline & & & \multicolumn{3}{|c|}{ Markaya Yönelik Tüm Yorumlar } \\
\hline & & & Olumsuz & Olumlu & Toplam \\
\hline & & $\mathrm{N}$ & 49 & 0 & 49 \\
\hline & & \% (Markaya Yönelik Tüm Yorumlar içinde) & 67,1 & 0,0 & 33,1 \\
\hline & Olumsuz & $\%$ (Toplam içinde) & 33,1 & 0,0 & 33,1 \\
\hline \multicolumn{2}{|l|}{ Reklama } & $\mathrm{N}$ & 24 & 75 & 99 \\
\hline Yönelik & Tüm & \% (Markaya Yönelik Tüm Yorumlar içinde) & 32,9 & 100,0 & 66,9 \\
\hline Yorumlar & Olumlu & $\%$ (Toplam içinde) & 16,2 & 50,7 & 66,9 \\
\hline \multirow[t]{3}{*}{ Toplam } & & $\mathrm{N}$ & 73 & 75 & 148 \\
\hline & & \% (Markaya Yönelik Tüm Yorumlar içinde) & 100 & 100 & 100 \\
\hline & & $\%$ (Toplam içinde) & 49,3 & 50,7 & 100,0 \\
\hline
\end{tabular}

\section{Emoji Kullanımı}

Duygu ve düşüncelerin sembollerle anlatılmasını sağlayan emojiler de araştırma kapsamında kodlanmıştır. Emojiler hem olumlu ve hem de olumsuz ifadeleri içerebilmektedir. Ayrıca izleyici yorumlarında kullanılan emojilerin marka veya reklam öğelerinden hangisine yönelik olduğu belirsizdir. 
Dolayısıyla emojilerin ayrı bir ana kategori altında değerlendirilmesinin daha uygun olacağına kanaat getirilmiştir.

Tablo 7 Emojiler

\begin{tabular}{lll}
\hline EMOJi TÜRÜ & $\mathrm{N}$ & $\%$ \\
\hline Kalp & 28 & 16,6 \\
Alkış & 25 & 14,8 \\
Üzgün & 25 & 14,8 \\
Ağlama & 21 & 12,4 \\
OK el işareti & 15 & 8,9 \\
Dua & 13 & 7,7 \\
Gülme/Tebessüm & 11 & 6,5 \\
Diğer & 10 & 5,9 \\
Çiçek & 7 & 4,1 \\
Maske & 6 & 3,6 \\
Kızgın/küfür & 5 & 3 \\
Kalpli göz & 2 & 1,2 \\
Kucaklama & 1 & 0,6 \\
\hline TOPLAM & $\mathbf{1 6 9}$ & $\mathbf{1 0 0}$
\end{tabular}

İzleyici yorumları incelendiğinde toplam 169 adet emoji kullanıldığı tespit edilmiştir. En yüksek kullanım oranına sahip emojilerin ise kalp $(\% 16,6, n: 28)$, alkış (\%14,8, n:25), üzgün yüz $(\% 14,8, n: 25)$ ve ağlama (\%12,4, n:21) olduğu anlaşılmıştır. Kızgın yüz/küfür emojisinin kullanım oranının \%3 (n:5) olduğu tespit edilmiştir. Tablo 7'de yer alan bulgular ışığında emoji kullanımının ağırlıklı olumlu duyguların ifade edilmesinde tercih edildiği söylenebilir.

\section{SONUÇ}

Koronavirüs 2019 yılının sonlarına doğru ilk kez Çin'de ortaya çıkmış ardından 2020 yılı içinde tüm dünyaya yayılmıştır. Tarih boyunca tüm salgın hastalıkların sosyal değişime yol açtı̆̆ı (Reeves ve diğerleri, 2020) düşünüldüğünde bu süreçte yaşamın her alanında köklü değişimlerin olması şaşırtıcı değildir. Bu değişim sürecinden reklam içerikleri de etkilenmiştir. Özellikle pandeminin ilk dönemlerinde Covid-19 temalı sosyal reklamlara çeşitli mecralarda sıklıkla rastlanmıştır. Reklam içeriklerindeki yaşanan bu değişimin yanında reklam izleyicisinin yaşamında da değişimler meydana gelmiş, bireyler bu süreçte eve kapanma, maske kullanma ve sosyal mesafe gibi Covid-19 tedbirleri ile günlük yaşantılarını yeniden düzenlemek durumunda kalmışlardır. Diğer yandan bu ölçekteki bir pandeminin yüzyılı aşkın bir 
süredir görülmediği göz önünde bulundurulduğunda bu alandaki tüketici araştırmalarının sınırlı olduğu (Jones ve diğerleri, 2010) anlaşılmıştır. Hem reklam içeriklerinde hem de reklam izleyicisinde yaşanan bu değişim sürecinde, bireylerin Covid-19 temalı sosyal reklamlara yönelik düşüncelerinin ortaya konması amacıyla bu araştırma gerçekleştirilmiştir.

Sosyal pazarlamanın ana amacı kar elde etmek değil, sosyal amaçlar doğrultusunda hareket ederek uzun vadeli toplumsal çıkarları göz önünde bulundurmaktır (Mucuk, 2001, s. 16). Dolayısıyla sosyal pazarlamanın bir öğesi olan sosyal reklamlar söz konusu olduğunda da öncelikli amaç kar elde etmek olmamalıdır. İzleyici yorumlarında reklam ve markaya yönelik olumsuz değerlendirmeler içinde olumsuz sıfat olarak "kan emici, dolandıııı, kazıkç" vb. ifadelerin kullanılması, yapılan bu sosyal reklamların amacına tamamen ulaşmadığının; başka bir ifade ile ilgili markanın kendi çıkarları doğrultusunda hareket ettiğine yönelik bir algının izleyicilerin bir kısmında hakim olduğunun göstergesi olarak yorumlanabilir. Bireylerin herhangi bir sosyal reklama yönelik yaptıkları bu olumsuz değerlendirmeler, marka tarafından gerçekleştirilen iletişim faaliyetinin samimiyetsiz bulunduğu şeklinde yorumlanabilir. İzleyicilerin sosyal içerikli bir reklamı izlediğinde, reklam veren markanın maddi çıkarlarını düşündüğüne dair yorum yapıyor olması, ilgili reklamın arzulanan etkisinin ulaşmadığının göstergesidir. Dolayısıyla sosyal reklamlar söz konusu olduğunda reklam verenin, reklam kampanyasından önceki edimlerinin yaptığı iletişim faaliyetleri ile tutarlı olması gerektiği söylenebilir. Bu bağlamda tüketicinin gözünde önemli olan unsurun samimiyet ve tutarlılık olduğu sonucuna varılabilir. Sadece belirli dönemlerde, herhangi bir akımı takip edercesine yapılan sosyal reklam kampanyaları izleyiciler tarafından genellikle samimi bulunmamakta, olumlu şekilde değerlendirilmemektedir. Reklam veren markanın topluma sağladığı fayda ile reklam çalışmaları arasında bir tutarlılık olması gerekir. Kısaca kriz dönemlerinde markanın sürece karşı duyarlı davranması, bu zorlu süreçte bireylerin yaşantılarını kolaylaştırmak ve topluma bir katma değer sunabilmek adına bir şeyler yapması durumunda sosyal reklam kampanyalarının izleyiciler üzerinde arzu edilen etkiyi sağlayacağı öngörülebilir.

Covid-19 salgını sonucunda reklamlarda topluluk, birlik, beraberlik kavramlarına dayanan yaklaşımlar ağırlık kazanmıştır. "Hepimiz bu işte birlikteyiz" mesajı bu dönemdeki sosyal reklamların genel çerçevesini belirlemiş; bu krizin birleştirici bir güç olduğu ve bu salgından herkesin etkilendiği fikri reklamlarda hakim olmuştur (Sobande, 2020; Yetkin Cılızoğlu ve diğerleri, 2020). Araştırma kapsamında 
incelenen izleyici yorumlarında bu durumun yansımalarına rastlanmıştır. Ancak burada dikkat çeken bir unsur, birlik beraberlik mesajları izleyiciler tarafından vurgulanırken diğer yandan milli unsurların da sıklıkla dile getirilmiş olmasıdır. Özellikle marka ile ilgili olumlu görüşler arasında milli unsurların sıklıkla dile getirildiği anlaşılmıştır. Milli unsurlara ait değerlendirmelere reklama yönelik olumlu yorumlar arasında da rastlanmasına karşın bu oran, markaya yönelik yapılan olumlu değerlendirmeler içindeki kadar yüksek değildir. Dolayısıyla milli değerlere sahip çıkma, vatana hizmet vb. unsurların reklamın kendisinden ziyade marka imajına katkı sağladığı sonucuna varılabilir. Bu araştırmanın sonuçlarına göre Covid-19 salgını sürecinde reklam içeriklerinde verilen birlik beraberlik mesajlarının izleyiciler tarafından ağırıklı olarak milli duygular üzerinden anlamlandırıldığı tespit edilmiştir. Bu bağlamda milli duyguların (Vatana hizmet, Türk olmak, ülke sevgisi vb.) tüketiciler açısından belirleyici olabildiği söylenebilir. Bu durumun sadece Türkiye'ye özgü bir durum olup olmadığl; diğer ülkelerde Covid-19 temalı reklamlara yönelik izleyici görüşlerinde milli unsurların dile getirilip getirilmediği gelecek çalışmalarda incelenmelidir.

Söz konusu reklam içeriği olduğunda ise izleyicilerin odak noktalarının değiştiği anlaşılmaktadır. Sciuli ve Bebko $(2005$, s. 31-32) sosyal içerikleri reklamların ticari reklamlara oranla daha fazla duygusal öğe barındırdı̆̆ını belirtiler. Edelman Trust Barometer anketinin sonuçlarına göre ise tüketiciler pandemi döneminde neşeli ve eğlenceli mesajların uygunsuz olacağı görüşünde birleşmektedirler (Rogers, 2020). Bu araştırmadan elde edilen sonuçlara göre Covid-19 salgını ile ilgili reklamlarda en çok beğenilen unsur reklamların duygusal oluşudur. Bu durum Edelmen Trust Baramoter anketinin sonuçları ile tutarlılık göstermektedir. Duygusal içeriğe sahip bir reklam markanın bu konuda gösterdiği duyarlılığın bir yansıması olarak yorumlanabilir. Dolayısıyla Covid-19 salgını ile ilgili reklam içeriklerinin olumlu etki yaratabilmesi için duygusal öğeler barındırması ve eğlenceli içeriklere yer vermemesi gerektiği söylenebilir. Diğer yandan bazı izleyiciler tarafından reklamların duygusal içeriği olumsuz şekilde değerlendirilmiş; reklamlardaki duygusal tonun moral bozduğu, karamsarlık verdiği, üzücü olduğu yönünde de eleştiriler getirilmiştir. Sosyal reklamlar duygulara hitap etmeli ancak bunu duyguları istismar etmeyerek başarmalıdır.

Tüketicilerin pandemi ile başa çıkma yöntemlerinden biri de marka ile ilgili mevcut görüşenlerini değiştirmeleridir (Kirk \& Rifkin, 2020). Edelman Trust Barometer anketinin sonuçları markaların pandemi sürecinde yaptıklarının ve bu sürece verdikleri tepkinin, tüketicilerin gelecekteki satın alma kararlarında 
etkili olacağını; krize uygunsuz davranan markalardan ise tüketicilerin vazgeçeceklerini ortaya koymuştur. Ayrıca tüketiciler salgın sırasında güvendikleri markalardan haber almayı rahatlatıcı bulmakta, markaların salgın sürecinde nasıl aksiyon aldıklarını bilmek istemektedirler (Getreferralmd, 2020). Bu araştırma kapsamında da markaların Covid-19 salgınına yönelik gösterdiği duyarlııı̆a dair değerlendirmeler reklamlara yönelik izleyici yorumlarında yansımalarını bulmuştur. Koç grubunun otellerini sağlık çalışanlarına ücretsiz olarak açması, solunum cihazı üretme vb. gibi salgın sürecinde sağlanan toplumsal faydalar ve sürece gösterilen duyarlılık izleyicilerin takdirini toplarken; sürece duyarsız kalan markalar izleyicilerin eleştirilerine uğramıştır. Pandemi sürecinde bireylerin hayatlarını kolaylaştırabilecek bedava internet sağlama, ödeme kolaylığı sunma vb. olanakların sunulmaması eleştirilerin ana odağını oluşturmuştur. Diğer yandan ürün/hizmetlere yönelik olumlu değerlendirmelerin yüzdesinin düşük olduğu anlaşılmıştır. Bu durum salgın sürecinde izleyicilerin, kendilerine sunulan ürün/hizmetlerden ziyade markaların sürece göstermiş olduğu duyarlılık ve sağladıkları katkılara odaklanmalarından kaynaklanabilir. Marka ile reklama yönelik izleyici yorumları karşılaştırıldığında, markaya yönelik olumsuz görüş̧lere rağmen reklam için olumlu değerlendirmeler yapııdığına rastlansa da markalara yönelik olumlu görüşlerin beraberinde reklamın da olumlu değerlendirilmesini daha yüksek oranda sağladığı anlaşılmıştır. Özetle salgın hastalık gibi zorlu süreçlerde markaların duyarı davranmaları, hedef kitlelerini sağladıkları katkılar konusunda haberdar etmeleri ve reklam içeriklerini de bu yönde oluşturmaları gerektiği söylenebilir.

\section{EXTENDED ABSTRACT}

\section{Conceptual Framework}

Corona virus was first identified in China at the end of 2019 and later spread worldwide in 2020. As a result, life has become more complex and uncertainties and concerns about the future have increased. Moreover, business enterprises have suffered from huge economic losses and people have faced difficulties in making ends meet and have had to cope with future anxiety (Getreferralmd, 2020). Throughout history, all the pandemics ranging from black plague in the Middle Age to Spanish flu at the beginning of the $20^{\text {th }}$ century triggered remarkable social changes (Reeves et al.,2020). When we consider the fact that the world had not suffered from such a serious and extensive pandemic for more than a century, we see that there are limited number of consumer research conducted in marketing and 
advertising (Jones et al.,2010). Since Covid-19 pandemic is expected to cause a similar social change, there is a growing need to examine possible changes in consumer behaviors during such a serious pandemic.

Due to Covid-19 pandemic, marketing activities of companies have been affected by considerable changes that are more challenging than all economic and social fluctuations the world have experienced so far. Certain precautions taken to prevent the spread of the pandemic such as social distancing and quarantine has radically affected how business enterprises carry out their business activities. Inevitably, advertising contents have also changed due to these developments. It was observed that business enterprises have started to include public safety campaigns and other social marketing efforts in their communication activities more and more (He \& Harris, 2020). It was also found that the focus of the communication activities of many companies was to express their gratitude for those who cannot stay at home and have to work during the pandemic; especially health workers. In addition, new advertising and marketing approaches based on certain concepts such as community, unity and solidarity have emerged due to Covid-19 pandemic, during which the essence of marketing messages of many companies was "we are all in this together" (Sobande, 2020).

In short, Covid-19 pandemic have triggered radical changes in many areas ranging from business life to individual lives. However, how the opinions of changing consumers regarding Covid-19 related advertisements have been shaped is still a vague issue that needs further examination. Accordingly, this study aims to identify opinions of audiences about Covid-19 related advertisements.

\section{Research Methodology}

For the purposes of the study, audiences' comments about Covid-19 related advertisements broadcasted on YouTube were analyzed by using content analysis method. The audiences' comments were coded under three main categories: comments about the advertisement - comments about the advertiser brand; and emojis- and the findings were presented as frequency tables. Advertisements were determined by using homogeneous sampling method, which is a purposeful sampling method. In addition, YouTube Ads Leaderboard data were used to determine the advertisements. The period for the advertisements was limited to March 2020, during which 8 out of 10 advertisements watched most 
according to YouTube Ads Leaderboard were found to involve messages about Covid-19 pandemic. 444 valid audience comments were included in the analysis.

\section{Findings}

The analysis of audiences' comments about the advertisements revealed 189 positive comments. Under this category, the most common comment was that "the advertisement was emotional; i.e., it touches audiences' emotions" $(\% 30,2, n: 57)$. This finding might be due to the fact that audiences like emotional contents more when they suffer from a serious problem such as a pandemic. Positive adjectives were voiced by the audiences as the second most common positive comments $(\% 25,9, n: 49)$. Among these adjectives are "legendary", "impressive", "awesome", "number one" and "fabulous". Other positive comments that follow the use of "positive adjectives" are expressions of appreciation $(\% 13,2, \mathrm{n}: 25)$ and congratulation $(\% 10,2, \mathrm{n}: 22)$.

The number of negative comments by the audiences about the advertisements was 49 and the most common category was "negative adjectives" used for the advertisements $(\% 30,6, n: 15)$. The adjectives such as "absurd", "disgusting", "ridiculous" and "illogical" were coded under this category. The second most common category involved the following criticisms about the advertisements; the advertising arouses negative emotions and pessimism; and it is saddening and demoralizing $(\% 18,4, n: 9)$. The criticisms suggesting that use of masks and social distancing, which are among the precautions taken to prevent Covid-19 pandemic, are violated in these advertisements are other negative comments about these advertisements $(\% 14,3, \mathrm{n}: 7)$.

Among 78 positive evaluations about the business enterprises, the most common category was expressions of love for that brand (\%37,2, n:29). The phrases such as "My dear bank", "Luckily, I am a Turkcell subscriber", and "Luckily, you are in my life" were categorized under this category. Expressing gratitude to the advertiser brand was another positive comment category $(\% 29,5, n: 23)$, which was followed by comments about national values $(\% 16,7, n: 13)$. Among the positive comments about these national values are as follows: the advertiser brand is the pride of the country; it loves the country; it serves and invests for the country; it is patriot, and its name includes the words "Türk" (Turkcell) and 
"Türkiye" (Türkiye İş Bankası). In addition, sensitivity and supports of these brands during difficult times such as pandemic were reflected in audiences' comments (\%15,4, n:12)

Of 73 negative comments about the advertiser brands by the audiences, the most common category was the criticisms about products and services $(\% 47,9, \mathrm{n}: 35)$. The complaints such as high utility bills, high interest rates, poor internet connection and inefficient customer services were coded in this category. On the other hand, only one audience $(\% 0,5)$ reported his satisfaction for products / services as a positive comment about the advertiser brands, which is quite noteworthy.

\section{Conclusion}

The use of negative expressions by audiences for advertiser brands such as "bloodsucker, fraud, swindler etc." might imply that such advertisements do not achieve their purposes. In other words, there seems to be a dominant perception among the audiences suggesting that advertiser brands act by favoring their benefits. Similarly, these negative comments might be reflecting the fact that audiences find such communication activities carried out by advertiser brands quite insincere. In short, it might be predicted that social advertisement campaigns can have the desired effect on audiences if these brands are sensitive during such crisis and do something to make individuals' lives easier and provide an added value to the society.

Thanks to Covid-19, the approaches based on certain concepts such as community, unity and solidarity have become more dominant in advertising contents. The message "we are all in this together" sets the general framework for these advertisements and the idea that this crisis has been a unifying factor and everybody has been affected by this pandemic has become the dominant idea in these advertisements (Sobande, 2020; CIlızoğlu et al., 2020). The audiences' comments analyzed in this study also reflected this situation to some extent. What is more striking in the findings is that national values were frequently voiced by the audiences while unity and solidarity messages were also emphasized. These national values were often reflected in positive comments about the advertiser brands. In other words, the results of the current study revealed that "unity/solidarity" messages in advertisement contents published during Covid-19 pandemic are interpreted mainly through national values. In this respect, it might be concluded that national values (serving for the country, being a Turk, patriotism etc.) 
have a determining factor for consumers' choices. Similarly, national values were also voiced in positive comments about the advertisements. However, the reflection of national values in positive comments about the advertisements was not as intense as those in positive comments about the advertiser brands. Thus, it might be suggested that certain factors such as conservation of national values and serving for the country contribute mainly to the image of that brand.

When it comes to advertising content, it is understood that the focus of the audience has changed. Sciuli and Bebko (2005, s. 31-32) report that social advertisements involve more emotional content than commercial advertisements. According to the results of the current study, what is liked most by the audiences about Covid-19 related advertisements is their emotional content. An advertisement with an emotional content might be the reflection of the brand's sensitivity about this issue. Therefore, it might be concluded that Covid-19 related advertisements should include emotional content so that they can have a positive effect.

The study also found a number of audiences' comments focusing on brands' sensitivity about Covid-19 pandemic. The brands' failure to provide free internet and easy terms of payment throughout the pandemic has been criticized. In addition, the percentage of positive comments about products/services was found to be quite low, the reason of which might that the audiences focus on the sensitivity of these brands and their contributions rather than their products and services. In short, it might be concluded that, during difficult times such as a pandemic, advertiser brands should be sensitive about the problem, inform their target audience about their contributions to the process and design their advertisement contents accordingly.

\section{KAYNAKÇA}

Anwar, Y., \& El-Bassiouny, N. (2020). Marketing and the sustainable development goals (SDGs): a review and research agenda. S. Idowu, R. Schmidpeter, \& L. Zu (Dü) içinde, The future of the UN sustainable development goals (s. 187-207). Cham: Springer. doi:10.1007/978-3-030-211547_9

Bagozzi, R., \& Moore, D. (1994). Public service advertisements: emotions and empathy guide prosocial behavior. Journal of Marketing, 58(1), 56-70.

BBC. (2020). https://www.bbc.com/turkce/haberler-dunya-51177538 adresinden alındı

Bilgiç, B. (2016). İstanbul: İstanbul Aydın Üniveristesi Sosyal Bilimler Enstitüsü.

http://acikarsiv.aydin.edu.tr/bitstream/11547/2071/1/432601.pdf adresinden alındı 
Bilgin, N. (2010). Sosyal bilimlerde içerik analizi: teknik ve örnek çalışmalar. Ankara: Siyasal Kitapevi.

Cheng, H., Kotler, P., \& Lee, N. (2011). Social marketing for public health: global trends and succes stories. England: Jones and Bartlett Publishers.

Dann, S. (2010). Redefining social marketing with contemporary commercial marketing definitions. Journal of Business Research, 63(2), 147-153. doi:https://doi.org/10.1016/j.jbusres.2009.02.013

Gertner, D., \& Rifkin, L. (2018). Coca-Cola and the fight against the global obesity epidemic. International Business Review, 60(2), 161-173. doi:https://doi.org/10.1002/tie.21888.

Getreferralmd. (2020). https://getreferralmd.com/2020/04/healthcare-marketing-strategies-in-thetime-of-covid-19/ adresinden alındı

Google News. (2021). https://news.google.com/covid19/map?hl=tr\&mid=\%2Fm\%2F02j71\&gl=TR\&ceid=TR\%3Atr adresinden alındı

He, H., \& Harris, L. (2020). The impact of Covid-19 pandemic on corporate social responsibility and marketing philosophy. Journal of Business Research, 116, 176-182.

Jones, S., Waters, L., Holland, O., Bevins, J., \& Iverson, D. (2010). Developing pandemic communication strategies: preparation without panic. Journal of Business Research, 53(2), 126-132. doi:https://doi.org/10.1016/j.jbusres.2009.02.009

Karpen, I. O., \& Conduit, J. (2020). Engaging in times of COVID-19 and beyond: theorizing customer engagement through different paradigmatic lenses. Journal of Service Management, 31(6), 1163-1174. Retrieved from https://www.emerald.com/insight/content/doi/10.1108/JOSM05-2020-0156/full/html

Kassarjian, H. H. (1977). Content analysis in consumer research. Skip Nav Destination, 4(1), 8-18. doi:https://doi.org/10.1086/208674

Kataria, M., \& Larsen, K. (2009). Effects of social marketing on battery collection. Resources, Conservation and Recycling, 429-433. doi:https://doi.org/10.1016/j.resconrec.2009.03.003

Kirk, C. P., \& Rifkin, L. S. (2020). I'll trade you diamonds for toilet paper: consumer reacting, coping and adapting behaviors in the covid-19 pandemic. Journal of Business Research, 117, 124-131. doi:https://doi.org/10.1016/j.jbusres.2020.05.028

Kocasu, A. N. (2020, 4 13). Mediacat. https://mediacat.com/youtube-ads-leaderboard-turkiye-mart2020/ adresinden alındı

Kotler, P., \& Lee, N. (2006). Kurumsal sosyal sorumluluk. (S. Kaçamak, Çev.) İstanbul: Kapital Medya.

Kotler, P., \& Lee, N. (2007). Kamu sektöründe pazarlama. İstanbul: Mediacat.

Kotler, P., \& Levy, S. (1969). Broadening the concept of marketing. Journal of Marketing, 33(1), 10-15. https://www.jstor.org/stable/124874 adresinden alındı

Kotler, P., \& Zaltman, G. (1971). Social marketing: an approach to planned social change. Journal of Marketing, 35(3), 3-12.

https://www.jstor.org/stable/1249783?seq=1\#metadata_info_tab_contents adresinden alındı

Kotler, P., Roberto, N., \& Lee, N. (2002). Social marketing: improving the quality of life. Thousand Oaks California: Sage Publications.

Mucuk, i. (2001). Pazarlama ilkeleri. İstanbul: Tükmen Kitapevi. 
Öncü Arslanoğlu, S. (2020, 4 10). Mediacat: https://mediacat.com/cmo-society-ile-11-maddedecorona-sonrasi-yasam/ adresinden alındı

Öztürk, M. C. (2009). Sosyal boyutlu reklamlar. Ş. Yavuz (Dü.) içinde, Reklamın toplumsal yansımaları ve yeni reklam (s. 217-236). Ankara: Ütopya.

Reeves, M., Carlsson-Szlezak, P., Whitaker, K., \& Abraham, M. (2020, 4 3). Sensing and shaping the postcovid era. BCG: https://image-src.bcg.com/Images/BCG-Sensing-and-Shaping-the-PostCOVID-Era-Apr-2020-rev_tcm26-244426.pdf adresinden alındı

Rogers, D. (2020, 3 31). Campaign. Retrieved from https://www.campaignlive.co.uk/article/consumersputting-brands-notice-coronavirus-behaviour-study-finds/1678821

RSA. (2020, 4 16). RSA: https://www.thersa.org/press/releases/2019/brits-see-cleaner-air-strongersocial-bonds-and-changing-food-habits-amid-lockdown adresinden alındı

Sciulli, L. M., \& Bebko, C. (2005). Social cause versus profit oriented advertisements: an analysis of information content and emotional appeals. Journal of Promotion Management, 11(2-3), 17-36. doi:https://doi.org/10.1300/J057v11n02_03

Sobande, F. (2020). 'We're all in this together': commodified notions of connection, care and community in brand responses to COVID-19. 23(6), 1033-1037. doi:https://doi.org/10.1177/1367549420932294

The Ad Council. (2020, 4 27). Retrieved from Prnewswire: https://www.prnewswire.com/newsreleases/ad-council-launches-out-there-for-us-campaign-thanking-workers-on-the-frontlines-of-the-covid-19-pandemic-301047506.html

TrEuronews. (2020, 54). TrEuronews: https://tr.euronews.com/2020/05/04/dunyada-covid-19-salgn-n-ilk-100-gununde-yasananlar-ilk-nerede-ortaya-c-kt-nas-l-yay-Id adresinden alındı

Turan, M. (2020, 4 28). Anadolu Ajansı: https://www.aa.com.tr/tr/bilim-teknoloji/aa-yerli-solunumcihazinin-uretim-asamalarini-goruntuledi/1821021 adresinden alındı

Yetkin Cılızoğlu, G., Dondurucu, Z., \& Çetinkaya, A. (2020). Sosyal pazarlama bağlamında covid-19 salgını sürecinde gsm operatörlerinin Youtube reklamlarının analizi. Uluslararası Kültürel ve Sosyal Araştırmalar Dergisi, 6(1), 280-299. https://dergipark.org.tr/en/download/articlefile/1168380 adresinden alındı

Yıldırım, A., \& Şimşek, H. (2011). Sosyal bilimlerde nitel araştırma yöntemleri. Ankara: Seçkin.

Yüzer, A. (1989). Sosyal pazarlama yaklaşımı açısından sosyal amaçlı reklam kampanyaları ve bir uygulama: Türkiye aşı kampanyası. İstanbul: Marmara Üniversitesi Sosyal Bilimler Enstitüsü.

\section{EKLER}

\section{Ek 1. Kodlama Cetveli}

\section{Reklama Yönelik Değerlendirmeler}

Reklam içeriğine yönelik izleyiciler tarafından yapılan yorumları kapsar.

\section{Reklama Yönelik Olumlu Değerlendirmeler}

Reklamı yapıcı, pozitif, yararlı, uygun şekilde niteleyen ifadeleri içerir.

Duygusallık: Çok duygulandım, gözlerim yaşardı, ağlayacağım, çok dokunaklı vb. ifadeler. 
Olumlu Sıfat: Efsane, etkileyici, muhteşem, anlamlı, başarılı, fevkalade vb. ifadeler.

Takdir: Takdir ettim, helal olsun, emeğinize sağlık, bravo vb. ifadeler.

Tebrik: Kutluyorum, tebrik ederim vb. ifadeler.

Reklam Mesajı Yineleme: Reklam mesajının tekrar edildiği yorumları içerir: geçecek, sabredelim, sabret Türkiye'm gibi.

Milli Unsurlar: Reklama ait milli değerlere yönelik değerlendirmelerin markaya yönelik olanlardan farkı kuruma/markaya yönelik herhangi bir övgü içermemesidir. Vatanseverlik, vatana hizmet vb. gibi değerlendirmeler markaya yönelik milli unsurlar kapsamında kodlanmıştır. "Korona Türklerden güçlü değil", "ne mutlu Türk'üm diyene", "Türk gibisi yok", "Türkiye güçlü bir ülke", "Türkiye'yi seviyorum" gibi ifadeler ile birlik beraberlik çağrısı yapan izleyici yorumları bu kategoride ele alınmıştır.

Sağıı Çalışanları: "Kahraman doktorlar" vb. sağıı çalışanlarına yönelik olumlu değerlendirmeleri içerir.

\section{Reklama Yönelik Olumsuz Değerlendirmeler}

Reklamı yapııı ve yararlı olmayan, hiçbir sonuca ulaşmayan, gözetilen amaca veya beklenilene uygun olmayan, menfi, negatif şekilde niteleyen ifadeleri içerir.

Olumsuz Sıfat: Anlamsız, iğrenç, gereksiz, mantıksız vb. ifadeler.

Olumsuz Duygu: Reklamın olumsuz duygular uyandırdığı, üzücü olduğu, karamsarlık verdiği, moral bozucu, acıklı, sinir bozucu olduğu ve duygu sömürüsü yaptığına yönelik değerlendireler.

Covid-19 Önlemlerine Uymama: Cerrahi maske kullanımı ve sosyal mesafe kurallarının reklamlarda ihlal edildiğine yönelik eleştiriler.

Diğer: Bu kategoriler dışında kalan diğer olumsuz yorumlar.

Reklam Mesajını Reddetme: Bugünlerin geçici olduğu, sabredilmesi gerektiği yönündeki mesajların reddine yönelik ifadeler.

Diğer Emekçilerin Görülmemesi: Pandemi döneminde çalışmak zorunda kalan kuryeler, güvenlik görevlileri gibi diğer emekçilere reklamlarda yer verilmemesine yönelik olumsuz değerlendirmeler.

Sık Tekrar: Reklamın YouTube'da çok sık tekrar etmesi, yayını bölmesine yönelik eleştiriler.

\section{Markaya Yönelik Değerlendirmeler}

Reklam içeriğinden bağımsız olarak reklam veren markaya ait ifade edilen izleyici görüşlerini kapsar.

\section{Markaya Yönelik Olumlu Değerlendirmeler}

Markayı yapıcı, pozitif, yararlı, uygun şekilde niteleyen ifadeleri içerir.

Sevgi: Canım bankam, iyi ki Turkcelliyim, iş Bankam, iyi ki varsın Arçelik vb. ifadeler.

Teşekkür: Teşekkürler Turkcell, teşekkürler İş Bankası gibi marka adını dile getirerek teşekkürlerin ifade edilmesi. 
Milli Unusurlar: Markanın ülkenin gururu olması, ülkesini sevmesi, ülkesine hizmet etmesi ve yatırımlar yapması, vatansever olması; markanın isminde Türk (Turkcell) ve Türkiye (Türkiye İş Bankası) kelimelerinin geçiyor olması, vatana hizmet etmesi, istihdam sağlamasına yönelik ifadeler.

Duyarlılık: Koç Grubu'nun otellerini sağlık çalışanlarına açması, Arçelik'in solunum cihazı üretmeye başlamasına yönelik; halka hizmet etme, topluma katkı sağlama, kara gün dostu olma, umut verme, halkın yanında olma, güncel sorunlara duyarlı olma vb. türünden değerlendirmeler.

Ürün/Hizmet Beğeni: Müşteri hizmetlerinin pandemi şartlarında düzgün hizmet vermesi, kredi kartı limit artışı vb. gibi markanın ürün/hizmetlerinden duyulan memnuniyet belirten ifadeler.

\section{Markaya Yönelik Olumsuz Değerlendirmeler}

Markayı yapıcı ve yararlı olmayan, hiçbir sonuca ulaşmayan, gözetilen amaca veya beklenilene uygun olmayan, menfi, negatif şekilde niteleyen ifadeleri içerir.

Ürün/Hizmet Şikâyet: Faturaların yüksek gelmesi, faizlerin yüksek olması, internetin çekmemesi, müşteri hizmetlerinin yetersizliği vb. gibi ürün/hizmetlerin yetersizliği ile ilgili eleştiriler.

Olumsuz Sıfat: Markaya yönelik çıkarcı, samimiyetsiz, kan emici, soyguncu, dolandırıcı, kazıkçı, anlayışsız, yalancı gibi ifadeler.

Destek Olmama: Markaların pandemi gibi zorlu bir süreçte gereken desteği sağlamamasına yönelik eleştiriler: ödeme kolaylığı sağlamama, bedava internet vermeme, komisyon almaya devam etme, borç ertelememe vb. gibi.

Diğer: Markaya yönelik diğer olumsuz değerlendirmeler.

\section{Emojiler}

Kalp: $\odot \circledast \bigoplus \oslash \circledast$ gibi diğer kalp türleri.

Alkış:

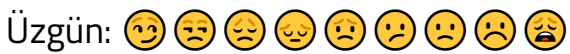

Ağlama: : :- :

OK el işareti: $凸$

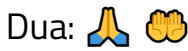

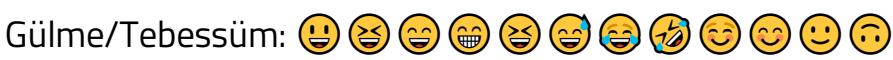

Diğer: bu kategoriler dışında kullanılan emojiler.

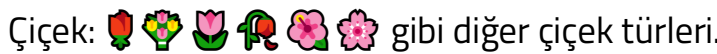

Maske:

Kızgın/küfür: $: 2$

Kalpli göz: 2

Kucaklama: 0 